\title{
A New Analytical Method for Oligosaccharides and Glycoconjugates Using Post-Source Decay Fragmentation by Matrix-Assisted Laser Desorption/Ionization Time-of-Flight Mass Spectrometry
}

\author{
MALDI-TOF質量分析による新しい糖鎖構造解析法： \\ ポストソースディケイ・フラグメント法による解析
}

\section{Yamagaki, Tohru}

National Institute of Bioscience and Human Technology, AIST, 1-1 Higashi, Tsukuba, Ibaraki 305-8566, Japan, FAX: 81 298-54-6135, E-mail: yamagaki@nibh.go.jp *Department of Molecular Biology, Saitama University, Urawa, Saitama 338-8570, Japan

Key Words : Structural analysis, Positional isomers, MALDI-TOFMS, Mass spectrometry, PSD fragmentation

\begin{abstract}
Structural analyses of oligosaccharides and glycoconjugates were performed by a new technique using matrix-assisted laser desorption/ionization time-of-flight mass spectrometry (MALDI-TOFMS). The sequential fragment ions of oligosaccharides were observed in the post-source decay (PSD) fragment spectra of MALDI-TOFMS. The relative ion intensity analyses of these MALDI-PSD fragment ions enable us to distinguish the structural isomers and to perform the linkage analysis. This technique is a powerful tool for fine structural analysis of oligosaccharides and glycoconjugates.
\end{abstract}

\section{A. Introduction}

Matrix-assisted laser desorption/ionization time-of-flight mass spectrometry (MALDI-TOFMS) consists of the ionization method of MALDI and the mass spectrometer by which time-of-flight of the ion is measured. It was thought that MALDI-TOFMS $(1,2)$ could be suited for the analysis of biomolecules as well as electrospray ionization (ESI) MS. This method has been mainly used to analyze proteins and peptides. There were few cases of the analysis of oligosaccharides (3-7). In this study, we tried to establish a new analytical method of oligosaccharides and glycoconjugates using MALDI-TOF mass spectrometry.

\section{B. MALDI-PSD Fragment Analysis}

The post-source decay (PSD) fragment analysis like MS/ MS measurement can also be performed by a MALDI-TOFMS instrument with the reflector [MALDI-PSD fragment method $(7,8)]$. In the MALDI-PSD fragmentation of neutral oligosaccharides, mainly glycosidic linkages cleave and the sequential
要 約

MALDI-TOF 質量分析法を用いた新しい糖鎖構造解析法の確 立を試みた。MS/MS様のフラグメントイオンが得られるMALDIMS ポストソースディケイ (PSD) フラグメント法では主にグリコ シド結合の切断によりフラグメントイオンが生成する。これらフ ラグメントイオンのイオン強度を詳細に議論することで構造異性 体の区別や結合様式の特定が可能であった。MALDI-PSD フラグ メント法は極微量での測定も可能であるため、今後糖鎖生物学な どの分野でも幅広く応用されることが期待できる。

質量分析法による不揮発性の生体物質の解析は、近年エレク トロスプレーイオン化 (ESI) 法やマトリクス支援レーザー脱離型 イオン化 (MALDI) 法などのイオン化法の出現により飛躍的に発 展した。特にMALDI 法と飛行時間型質量分析計 (TOFMS) を組 み合わせた MALDI-TOFMS $(1 、 2)$ は、従来タンパク質などで広 く応用されてきたが、糖鎖への応用は少なかった(3-7)。そこで 本研究ではこの MALDI-TOFMS を用いた新しい糖鎖構造解析法 について詳細に研究した。

\section{B. MALDI-PSD フラグメント法}

リフレクターを備えたTOF-MSでは分子イオンを親イオンと したポストソースディケイ (PSD) フラグメントイオンを観測し、 MS/MS様フラグメントイオン解析も可能である(MALDI-PSD フ ラグメント法 $(7 、 8))$ 。の手法によるオリゴ糖鎖の解析では、主 にグリコシド結合の切断によりフラグメントイオンが生成するの

*Former address. 
analysis of sugar chains can be performed. In the case of the analyses of xyloglucan oligosaccharides, the MALDI-PSD fragment ions produced both from the reducing and non-reducing ends ( $\mathrm{Y}$ type and $\mathrm{B}$ type fragment ions (9)) were observed simultaneously. The fragment ions produced by multi cleavage of glycosidic linkage were also observed (10-12). These points differ from FAB-MS spectra (13-16).

In our study, fine structural analyses of oligosaccharides were achieved by the relative ion intensity analysis of MALDIPSD fragmentation. All mass spectra were measured by a MALDI-TOFMS using a curved-field reflector which enables the simultaneous detection of the precursor ion and all fragment ions (17). Here, the structural analyses of cyclodextrin derivatives are shown. The sugar branched cyclodextrin derivatives were analyzed by the FAB-MS spectra in which the fragment ions were produced only from the branch (18-21). We carried total and fine structural analysis of the branched cyclodextrin derivatives by a new technique of MALDI-PSD fragmentation method.

\section{Structural Analyses of Sugar Branched Cyclodextrin Derivatives by MALDI-PSD Fragmentation Method}

\section{Difference between Cyclodextrin and Branch Part, and be-}

\section{tween Structural Isomers}

The sugar branched cyclodextrin (CD) derivatives of $\gamma$ CD, G1,G1- $\alpha \mathrm{CD}, \mathrm{G} 2-\alpha \mathrm{CD}$ (Fig. 1) consist of eight $\alpha-\mathrm{D}-$ glucopyranoses, which have the same molecular weight. These structural isomers were distinguished by the MALDI-PSD frag-
で、糖鎖の配列解析に用いられる。植物細胞壁キシログルカ ン・オリゴ糖鎖の分析では還元末端側、非還元末端側の両側か らのフラグメントイオン(Y-type, B-type フラグメントイオン(9)) が同時に観測され、複数のグリコシド結合が同時に切断されて 生じるフラグメントイオンも観測可能であった(10-12)。これら の点は従来用いられていた FAB-MS 法による解析(13-16)と異な る利点である。

本研究の特徵、新しい点はこれらPSDフラグメントイオン の相対イオン強度を詳細に議論し、より詳しい糖鎖構造の解析 を試みた点である。フラグメントイオンの相対強度を詳細に議 論するために全てのイオンを同時に検出できるリフレクターを 用いた(17)。ここではシクロデキストリン $(\mathrm{CD})$ 糖鎖誘導体の解 析例を示す。これらの化合物のFAB-MS 法による解析では分岐 部分のみからフラグメントイオンが生成する(18-21)。ここでは 分岐 $\mathrm{CD}$ 誘導体の分岐部分、 $\mathrm{CD}$ 部分両方を含めた構造解析を MALDI-PSDフラグメント法によって行った結果について述べ る。

C. MALDI-PSD フラグメント法による分岐シクロデキストリン 誘導体の構造解析

環状構造と分岐構造の区別、および構造異性体の区別

第1図に示す3種類のCDおよびその誘導体 $\gamma \mathrm{CD}$, マルトシル$\alpha \mathrm{CD}(\mathrm{G} 2-\alpha \mathrm{CD})$, ジグリコシル $\alpha \mathrm{CD}(\mathrm{G} 1, \mathrm{G} 1-\alpha \mathrm{CD})$ はそれぞれ全 く同じ分子量を持ち、全て $\alpha-\mathrm{D}-$ グルコピラノース8残基から構成 されており、それぞれを区別することは困難であるが、MALDIPSD フラグメント法によってそれぞれを明瞭に区別することが

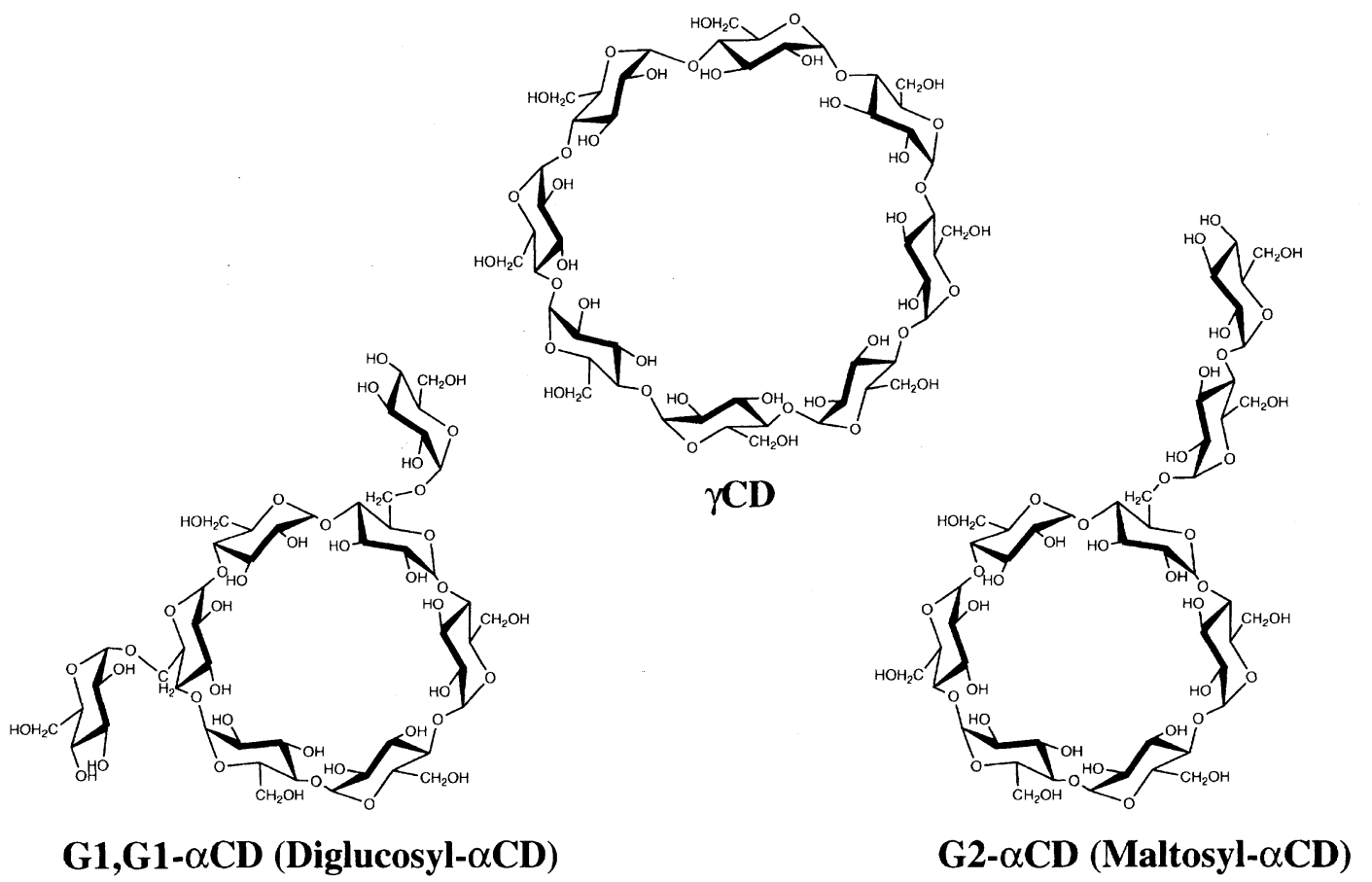

Fig.1. Structure of sugar branched cyclodextrin derivatives. 


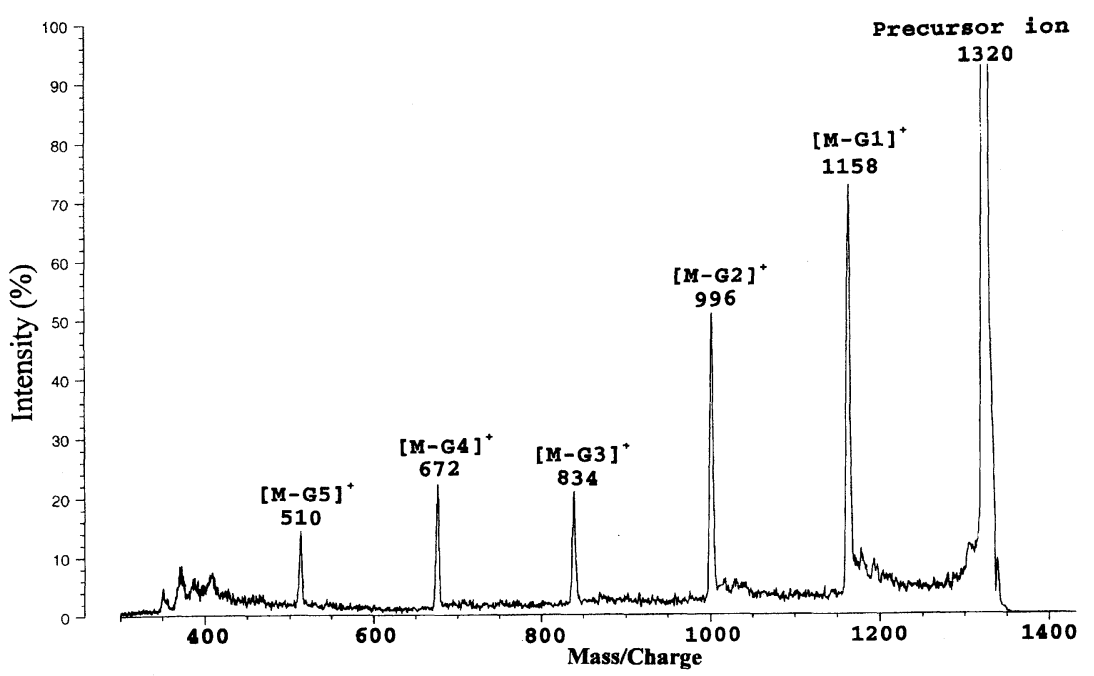

Fig. 2. MALDI-PSD fragment spectrum of G2- $\alpha$ CD.

mentation method (22-24).

In the PSD-fragment spectrum of G2- $\alpha \mathrm{CD}$ with maltosylbranch (Fig. 2), the fragment ions [M-G1]+ and [M-G2]+ have higher intensities than [M-G3, G4, G5]+ ions with lower intensities. The numbers of higher fragment ions were the same to those of branched sugar residues (G2). Thus, it was assumed that the higher fragment ions were produced from the branch part mainly, and that the lower fragment ions [M-G3, G4, G5]+ were produced from the cyclodextrin part. The fragment ions from the branch part require one-site cleavage in $G 2-\alpha C D$ as shown in Fig. 3, which have much higher intensity. The fragment ions from the cyclodextrin part require two-site cleavage, which have lower intensities. Thus, the one-site cleavage fragment ions have much higher intensities than the two-site cleavage ions in MALDI-PSD fragmentation. These results strongly indicate that MALDI-PSD fragment spectrum reflect the fine
できた(22-24)。

分岐構造を持つマルトシル- $\alpha \mathrm{CD}(\mathrm{G} 2-\alpha \mathrm{CD})$ では、[M-G1]+、 [M-G2]+イオンの強度がより高く、フラグメントイオン [M-G3] +、[M-G4]+および [M-G5]+の強度はより低く観測される(第 2 図)。強度の高いフラグメントイオン([M-G1]+、[M-G2]+)の数は 直鎖の分岐糖鎖の数 $(\mathrm{G} 2)$ に一致することから、強度の高い $[\mathrm{M}-$ $\mathrm{G} 1]+$ 、[M-G2]+イオンは分岐マルトシル $(\mathrm{G} 2)$ 上り生じ、より強 度の低い [M-G3, -G4, -G5]+イオンは環状のシクロデキストリン $(\alpha \mathrm{CD})$ 部分から生じていると推論できる(第 3 図)。G2- $\alpha \mathrm{CD}$ では 分岐構造部分からはグリコシド結合 1 カ所切断によってフラグ メントイオンが生じるが、環状構造 (CD) 部分では、フラグメン トイオン生成に 2 カ所のグリコシド結合切断が必要である。す なわち MALDI-PSD フラグメント解析では、グリコシド結合 1 カ所切断で生成するイオンは 2 カ所切断の必要なフラグメント イオンよりもイオン強度が高く観測される事が分かった。これ らの結果から、MALDI-PSD フラグメント・スペクトルはオリゴ

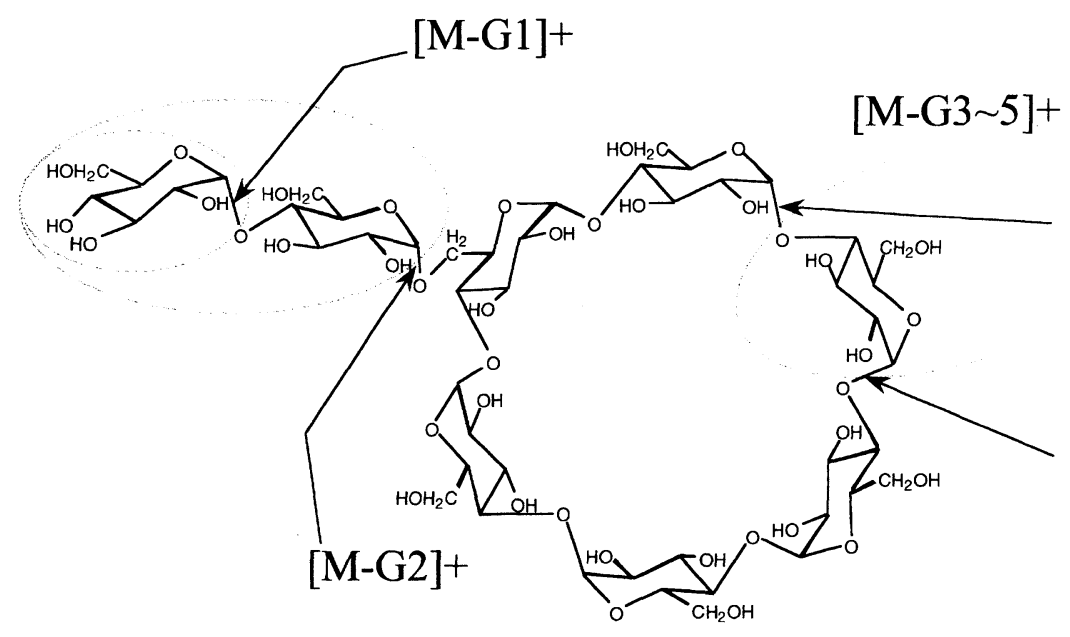

Fig.3. Schema of the fragmentation of G2- $\alpha$ CD. 

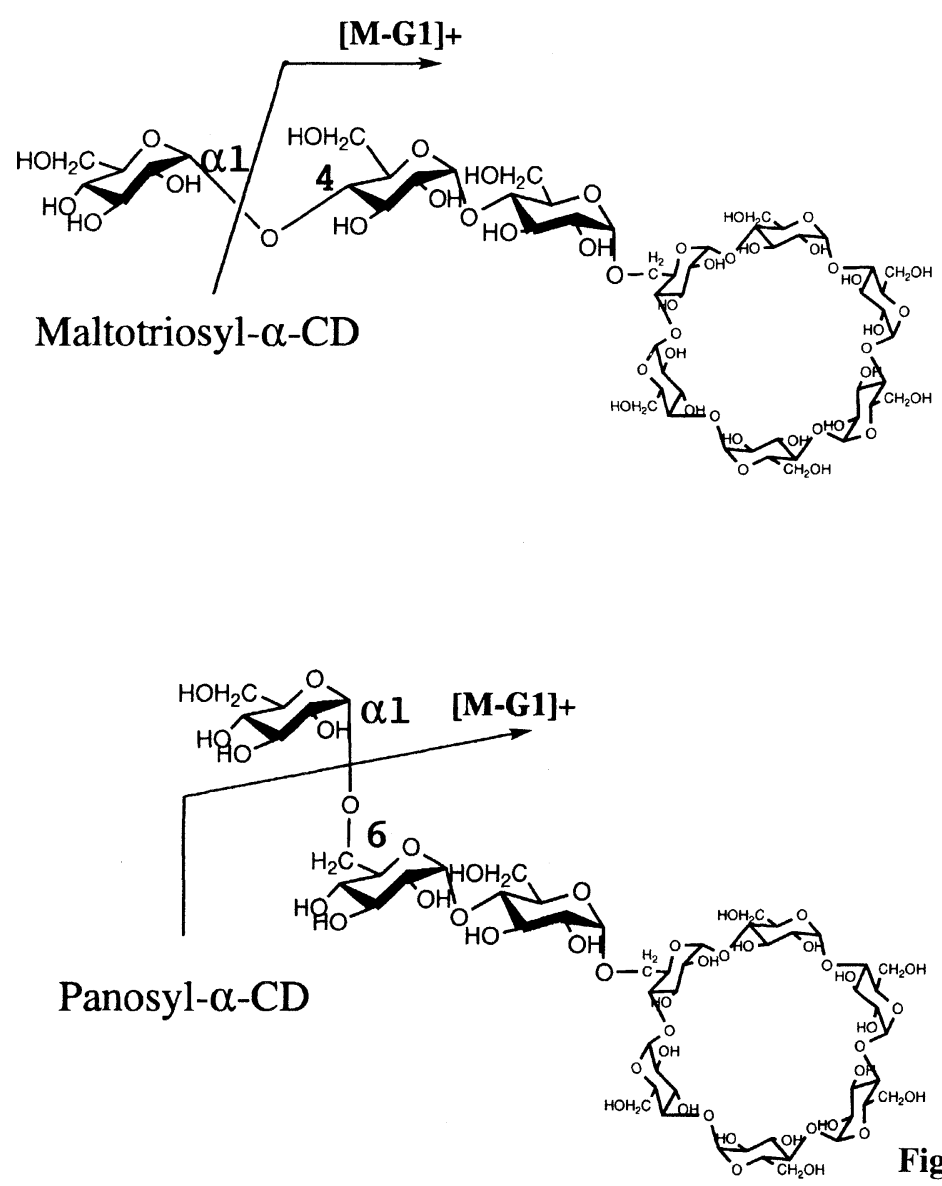

Fig.4. Structure of maltotriosyl- $\alpha \mathrm{CD}$ and panosyl- $\alpha \mathrm{CD}$.

structure of oligosaccharides. Three isomers of cyclodextrin derivatives were distinguished clearly by this method. The branch structures of oligosaccharides can be analyzed by this MALDI-PSD fragmentation method (22-27).

\section{Linkage Analysis}

Next, linkage analyses of oligosaccharides are performed by this MALDI-PSD fragmentation method. Maltotriosyl- $\alpha C D$ and panosyl- $\alpha \mathrm{CD}$ differ only at the glycosidic linkages on the non-reducing end of the branch (Fig. 4). Maltotriosyl part is Glc $\alpha 1-4 G l c \alpha 1-4 G l c \alpha 1-6-C D$, and panosyl part is Glc $\alpha 1-$ 6Glc $\alpha 1-4$ Glc $\alpha 1-6-C D$. Comparing their PSD fragment spectra, the relative intensity of the [M-G1]+ of maltotriosyl- $\alpha \mathrm{CD}$ is much higher than that of panosyl- $\alpha \mathrm{CD}$. These results strongly indicate that the glycosidic linkage of $\alpha 1-4$ cleaves much more easily than that of $\alpha 1-6$ in MALDI-PSD fragmentation, which were consistent with those of pullulan (28).

The other glycosidic linkages have been analyzed by this MALDI-PSD fragmentation method. In the studies of xyloglucan oligosaccharides, it was revealed that the glycosidic linkage of $\alpha 1-6$ cleaves much more easily than that of $\beta 1-4$ linkage (29). MALDI-PSD fragmentation method is also useful for the structural analysis of glycoconjugates such as sialyl oligosaccharides and the structural isomers of lactotetraoses (30-32).
糖鎖の詳細な構造をよく反映していることがわかる。先に第 1 図に示した 3 種の糖鎖構造異性体もこの手法で明暸に区別する ことができ、MALDI-PSD 法が分岐構造の解析に有用な手法であ ることが解る(22-27)。

\section{D. 結合様式の解析}

さらに、MALDI-PSD フラグメント法によってグリコシド結 合の結合様式の解析を試みた。マルトトリオシル- $\alpha \mathrm{CD}$ (Glc $\alpha 1$ 4Glc $\alpha 1-4 \mathrm{Glc} \alpha 1-6-\alpha \mathrm{CD})$ とパノシル $-\alpha \mathrm{CD}$ (Glc $\alpha 1-6 \mathrm{Glc} \alpha 1-4 \mathrm{Glc} \alpha 1-6-$ $\alpha \mathrm{CD})$ とは、分岐部分オリゴ 3 糖の非還元末端残基の結合様式の みが異なる置換位置異性体糖鎖である(第 4 図)。それぞれのPSD フラグメントスペクトルを解析するとマルトトリオシル- $\alpha \mathrm{CD} の$ [M-G1]+イオンはパノシル $-\alpha \mathrm{CD}$ ものよりも相対的にイオン強 度が高く観測された。このことはMALDI-PSD フラグメント法に 扔いて、 $\alpha 1-4$ 結合の方が $\alpha 1-6$ 結合よりも切断されやすい事を示 している。さらに他の糖鎖化合物プルランについて検討し、上 述の規則が一般性の高い事が分かった(28)。

さらに他のグリコシド結合についても種々の糖鎖化合物を 解析し、MALDI-PSD フラグメンテーションでのグルコシド結合 の切断されやすさについて解析を行った。キシログルカン糖鎖 の解析では $\alpha 1-6$ 結合と $\beta 1-4$ 結合の違いを解析し、 $\alpha 1-6$ 結合の方 が 1-4 結合よりも切断されやすいという結果を得た(29)。ま た、複合糖質の解析においてもこのMALDI-PSD フラグメント法 は有用であった。例えば結合位置のことなる構造異性体ラクト テトラオース類の区別やシアル酸を含む糖鎖の解析が可能で 
Since mass spectrometry is a femto or atto mole level analytical method and never requires any derivatization such as permethylation, the MALDI-PSD fragmentation method is very useful for the fine structure analysis of glycoconjugates and oligosaccharides.

\section{E. Conclusion}

The new technique of post-source decay (PSD) fragmentation analysis by MALDI-TOF mass spectrometry, in which the relative intensities of the sequential fragment ions are examined, enables determination of linkage types and distinction of structural isomers in oligosaccharides. The MALDI-PSD fragmentation method is a very powerful tool in the analysis of glycoconjugates and for glycobiology.

\section{Acknowledgements}

The author is grateful to Assoc. Prof. Maeda, Masaakira (Saitama Univ., Japan), Prof. Nakanishi, Hiroshi (National Institute of Bioscience \& Human-Technology, Japan), and Prof. Yoshioka, Michikazu (Saitama Univ., Japan) for many helpful discussions and suggestions throughout the course of this work. Thanks to Dr. Kawabata, Shin-ichiro (Shimadzu Corp., Kyoto, Japan) for his technical advice, and to Assoc. Prof. Tsumuraya, Yoichi (Saitama Univ., Japan) for his helpful advices on the preparation of this manuscript.
あった(30-32)。以上より糖鎖構造解析に関して結合様式の解 析、構造異性体の区別などを含む非常に詳細な解析をこの MALDI-PSD フラグメンテーション法で行うことが可能であり、 複雑な誘導化などを必要としない糖鎖の新しい結合様式解析法 が確立できると考えている。

\section{E. まとめ}

MALDI-TOF 質量分析による新しい糖鎖構造解析法に於い て、グリコシド結合の切断によって生じるシークェンシャルな PSD フラグメントイオンのイオン強度を詳細に議論すること で、糖鎖の配列情報だけでなく結合様式の決定や構造異性体間 の区別などが可能であった。この手法は複合糖質も解析できる ため、生体内の微量な活性糖鎖の解析に有用な手法であると考 えられ、近年研究の進むグリコバイオロジーの分野でも幅広い 応用が考えられる。

\section{謝 辞}

本研究は埼玉大学理学部分子生物学科生体物質研究室およ び通商産業省工業技術院生命工学工業技術研究所生体物質部生 体物質化学研究室で行われたものであり、その間終始ご指導ご 鞭撻を賜わりました埼玉大学理学部助教授 前田昌徹先生およ び生命工学工業技術研究所生体物質部総括研究室長、東京理科 大学基礎工学部教授 中西洋志先生に深甚の謝意を表します。 また主指導教官としてご指導くださいました埼玉大学理学部教 授 吉岡道和先生、研究の技術的な面でご指導いただきました 島津製作所、川畑慎一郎先生、さらに本稿執筆の機会を与えて くださいました埼玉大学理学部助教授 円谷陽一先生に深謝い たします。

\section{References}

1. Tanaka, K., Waki, H., Ido, Y., Akita, S., Yoshida, S., and Yoshida, T., (1988) Rapid Commun. Mass Spectrom., 2, 151-153

2. Karas, M., and Hillenkamp, F., (1988) Anal. Chem., 60, 2299-2301

3. Mock, K. K., Davey, M. And Cottrell, J. S., (1991) Biochem. Biophys. Res. Commun., 177, 644-651

4. Stahl, B., Strupat, M., Karas, M., and Hillenkamp. F., (1991) Anal. Chem., 63, 1463-1466

5. Harvey, D. J., (1993) Rapid Commun. Mass Spectrom., 7, 614-619

6. Yamagaki, T., Maeda, M., Kanazawa, K., Ishizuka, Y., and Nakanishi, H., (1996) Biosci. Biotechnol. Biochem., 60, $1222-1228$

7. Kaufmann, R., (1995) J. Biotechnol., 41, 155-175.

8. Kaufmann, R., Kirsch, D., and Spengler, B., (1994) Int. J. Mass Spectrom. Ion Process, 131, 355-385

9. Domon, B., and Costello, C. E., (1988) Glycoconjugate J., 5, 397-409

10. Yamagaki, T., Mitsuishi, Y., and Nakanishi, H., (1997) Biosci. Biotechnol. Biochem., 61, 1411-1414

11. Yamagaki, T., Mitsuishi, Y., and Nakanishi, H., (1998) Chem. Lett., 1998, 57-58

12. Yamagaki, T., Mitsuishi, Y., and Nakanishi, H., (1997) Glycoconjugate J., 14, s110

13. York, W. S., Halbeek, H., Darvill, A. G., and Albersheim, P., (1990) Carbohydr. Res., 200, 9-31

14. Kiefer, L. L., York, W. S., Albersheim, P., and Darvill, A. G., (1990) Carbohydr. Res., 197, 139-158

15. Hisamatsu, M., York, W. S., Darvill, A. G., and Albersheim, P., (1992) Carbohydr. Res., 227, 45-71

16. York, W. S., Harvey, L. K., Guillen, R., Albersheim, P., and Darvill, A. G., (1993) Carbohydr. Res., 248, 285-301

17. Cornish, T. J., and Cotter, R. J., (1994) Rapid Commun. Mass Spectrom., 8, 781-785

18. Koizumi, K., Tanimoto, T., Okada, Y., Nakanishi, N., and Kato, N., (1991) Carbohydr. Res., 215, 127-136

19. Koizumi, K., Tanimoto, T., Fujita, K., Hara, K., Kuwahara, N., and Kitahata, S., (1993) Carbohydr. Res., 238, 75-91

20. Koizumi, K., Tanimoto, T., Okada, Y., Hara, K., T., Fujita, Hashimoto, H., Kitahata, S., (1995) Carbohydr. Res., 278, 129-142

21. Koizumi, K., Tanimoto, T., Okada, Y., Takeyama, S., Hamayasu, K., Hashimoto, H., Kitahata, S., (1998) Carbohydr. Res., 314, 115-125

22. Yamagaki, T., Ishizuka, Y., Kawabata, S., and Nakanishi, H., (1996) Rapid Commun. Mass Spectrom., 10, 1887-1890

23. Yamagaki, T., Ishizuka, Y., Kanazawa, K., and Nakanishi, H., (1998) Proceeding of 8th Int. Symposium on Cyclodextrins, Santiago de Compostela, Kluwer Academic Publishers., in press.

24. Yamagaki, T., Bunseki Kagaku, in press.

25. Yamagaki, T., Mitsuishi, Y., and Nakanishi, H., (1998) Tetrahedron Lett., 39, 4051-4054

26. Yamagaki, T., and Nakanishi, H., (1998) Rapid Commun. Mass Spectrom., 12, 1069-1074

27. Yamagaki, T., Mitsuishi, Y., and Nakanishi, H., (1998) Biosci. Biotechnol. Biochem., 62, 2470-2475

28. Yamagaki, T., Ishizuka, Y., Kawabata, S., and Nakanishi, H., (1997) Rapid Commun. Mass Spectrom., 11, 527-531 
29. Yamagaki, T., Mitsuishi, Y., and Nakanishi, H., (1998) Rapid Commun. Mass Spectrom., 12, 307-311.

30. Nakanishi, H., and Yamagaki, T., (1999) Glycoconjugate J., 16, S111 (Abstracts of XVth Int. Symposium on Glycoconjugates, Tokyo, Japan)

31. Yamagaki, T., and Nakanishi, H., (1999) Glycoconjugate J., 16, S111 (Abstracts of XVth Int. Symposium on Glycoconjugates, Tokyo, Japan)

32. Yamagaki, T., and Nakanishi, H., (1999) Glycoconjugate J. (in press)

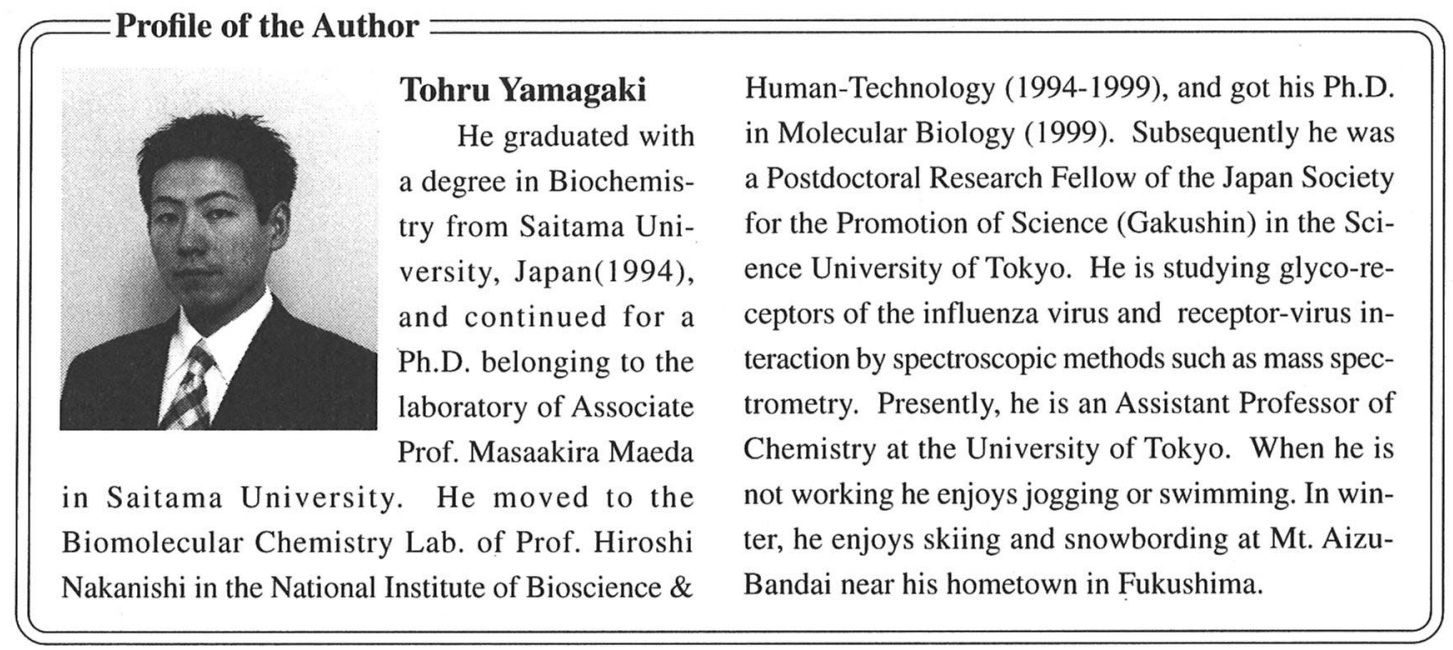

